\title{
Berczeli Péter
}

\section{Apróhirdetés-elemzés}

Az ingatlanpiac felmérésének célja a helyi lakóingatlanok piaci kínálatának és sajátosságainak feltárása városnegyedenként, illetve ingatlantípusonként. A legfontosabb feladat, hogy az eredmények tükrözzék, hogy milyen típusú ingatlanok iránt mutatkozik kereslet, melyek iránt állt meg az érdeklödés és mik azok a városjellegzetességek, amelyek hatással vannak az ingatlanpiacra. Ezek az eredmények pontosíthatják a tervezői munkát. Az ingatlanpiaci elemzésnél legfőképp az ingatlanközvetítő cégek munkatársaira lehet hagyatkozni, hiszen ök azok, akik megfelelö rálátással rendelkeznek a helyi ingatlanigényekre, lehetőségekre és piai árakra. A másik fontos adatszerzés a térséghez tartozó illetékhivatal ingatlan adás-vételi összesítésének vizsgálata. A harmadik, amellyel most bővebben is foglalkozni kívánok, az apróhirdetés-vizsgálat. Mindegyik adatszerzésnek megvannak az előnyei és a hátrányai is. A legfontosabb hátrányok mindig azok, hogy a tényleges ingatlanpiaci árak alacsonyabbak, vagy magasabbak a vizsgált adatoknál, hiszen a hirdetett ingatlanárak általában irányárak, amelyek a tapasztalatok alapján átlagosan 15-20 százalékkal magasabbak a valós ingatlanértéknél. Az illetékhivatal adatai legtöbbször alacsonyabbak, hiszen az illetékek és adók mértéke miatt a legtöbbször alacsonyabb adásvételi árat szoktak megadni az ingatlaneladásnál. Ha azonban ezeket a módszereket vegyesen használjuk, meglehetős pontossággal megismerhetjük a helyi ingatlanpiaci szerkezetet és ennek jellegzetességeit.

Az apróhirdetés-elemzés készítésénél az első feladat, hogy megtaláljuk azokat a hirdetőlapokat akár az Interneten, akár a helyi sajtóban, amelyekből elő tudjuk halászni a számunkra fontos adatokat. A nagyobb városokban több, kifejezetten ingatlanhirdetéssel foglalkozó lapot is találhatunk, a kisebb helységekben pedig leginkább a helyi lapokból informálódhatunk. A megfelelő lapok megtalálása 
után lehetőség szerint több év apróhirdetéseit kell megvizsgálni évszakos bontásban. A ingatlanpiaci tendenciákhoz érdemes az aktuális éven kívül a kettő, illetve öt évvel (pl.: 2005, 2003, 2001) korábbi adatokat is összegyüjteni, hiszen a változások feltérképezése segíthet bennünket egyes városrészek leszakadásának vagy épp felemelkedésének jelzésében. Az egyes évek vizsgálata során mind a négy évszak adataiból kell szemezgetni (pl.: január, április, július és október 2 hete), mert az ingatlanvásárlás szezonjától függően változhatnak az árak. A tapasztalatok szerint a legtöbb ingatlanvásárlás tavasszal és nyár végén történik, ebből kifolyólag az árak tavasszal és nyáron magasabbak, az őszi és téli szezonban viszont alacsonyabbak.

\section{Az adatok rögzítése}

Az adatok rögzítése során sok energiát takaríthatunk meg, ha eleve tudjuk, hogy az ingatlantípusokat hogyan szeretnénk kódolni. A rögzítést végezhetjük Exel-ben, vagy Spss-ben, illetve más táblázatkezelő programokban is. A táblázat váza a következő:

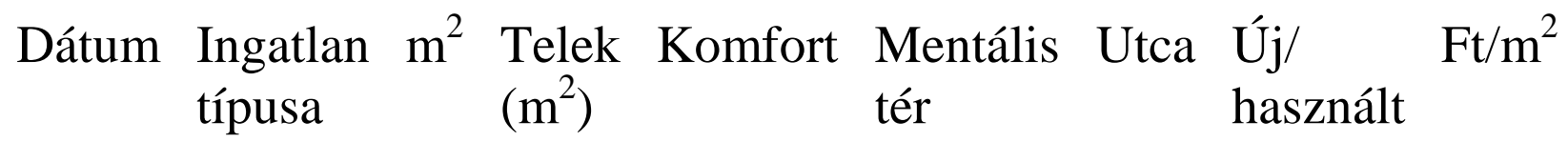

Sorszám: értelemszerüen 1-től fölfelé

Év, hónap, nap: a lejegyzett hirdetés megjelenési dátuma 
Ingatlan típusa:

- panellakás

- téglablokkos lakás

- téglaépítésü társasházi lakás

- lakóparki lakás/ház

- sorház

- ikerház

- családi ház

- üzlethelység/iroda

- egyéb, éspedig:

Természetesen ezeket a kategóriákat lehet bővíteni, illetve szűkíteni is. A lényeg, hogy minden olyan ingatlantípus felsorolásra kerüljön, amely jellemző a vizsgált településre.

Az ingatlan mérete:

Az ingatlanok árait az apróhirdetésekben nem négyzetméterre bontva adják meg $\left(\mathrm{Ft} / \mathrm{m}^{2}\right)$, hanem a teljes összeget szokták megjeleníteni. Az összehasonlításhoz a $\mathrm{Ft} / \mathrm{m}^{2}$-adatra mindenképp szükségünk van. Jelenleg Magyarországon a kisebb, 25-55 m2-es lakások árai jóval magasabbak, mint a nagyobb lakások/házak árai. Ez azonban változhat és változik is.

Telek:

A hozzá tartozó telek mérete $\mathrm{m}^{2}$-ben megadva. Ha nincs megjelölve a telek mérete, akkor értelemszerúen nincs telek az ingatlanhoz. Az önálló építési telek a mai magyar városokban rettentően ritka. A legtöbb régi, illetve rossz állapotú házakat ezért leginkább már csak telekárban szokták eladni. Fontos értékemelő tényező, ha az aktuális városrendezési szabályzat megengedi a társasházak építését, hiszen ez komoly ingatlanérték-növekedést produkál.

Komfortfokozat: (már majdnem mind összkomfortos)

- összkomfort (központi fütés + minden egyéb)

- komfort (egyedi fütés + minden egyéb)

- félkomfort (WC, vagy fürdő hiányzik)

- komfort nélküli (semmi nincs) 
A komfortfokozatok jelölése/elnevezése nem változott, azonban jelentése sokat. A panelépítések során az összkomfortos alatt a központi fütéssel és minden egyéb közmüvel ellátott lakásokat értették. Azonban ma már szinte minden ingatlant, legyen akár egyedi, akár központi fütése, összkomfortosnak jelölhetünk. A nagyobb városokban már elenyésző azoknak az ingatlanoknak a száma, amelyekbe a csatornán kívül ne vezettek volna be mindent, de kisebb települések vizsgálatakor fontos lehet ez a lehetőség is. A komfortfokozatok nem jelölnek értéksorrendet. Az összkomfortos nem automatikusan jobb vagy rosszabb a komfortos lakásoknál. Ezt jól lehet mérni, ha az ilyen típusú ingatlanok árait összehasonlítjuk.

Mentális tér: a megjelölt városrész neve

A mentális tér akkor fontos, ha a társadalmi hatástanulmányban külön foglalkozunk ezzel a módszerrel. Ha nem, akkor elég a hivatalos városrészeket megjelölni.

\section{Utca: utcanév}

Új/használt: a lakás állaga

A lakás állaga lehet sokkal árnyaltabb is, azonban az apróhirdetésekben ez ritkán körvonalazódik. Az ingatlanárakban viszont komolyan megjelennek például kormányzati döntések is, hiszen a lakásvásárlás támogatása ma Magyarországon szinte csak az új lakásokat érinti.

$\mathrm{Ft} / \mathrm{m}^{2}$ : négyzetméterár

A legtöbb táblázatkezelőben lehet olyan parancssorokat használni, amelyekkel ennek kiszámítása nagyon egyszerü az ár, illetve az ingatlan méretének ismeretében.

Az apróhirdetés-elemzés legfontosabb jelentősége, hogy minden városrészre/mentális térre lebontva megismerhetjük az ingatlanszerkezetet, és ugyanezt visszafelé, tehát a bejött adatokból megállapíthatunk különböző ingatlanspecifikus területeket is, amelyeket felhasználhatunk a településfejlesztési munkálatokhoz. 